\title{
Prolactin and the control of gonadotrophin secretion in the female
}

\author{
Alan S. McNeilly \\ MRC Unit of Reproductive Biology, Centre for Reproductive Biology, 37 Chalmers Street, \\ Edinburgh EH3 $9 E W, U . K$.
}

It is not intended that this paper should present an exhaustive review of the literature concerning the interaction between prolactin and gonadotrophin release. Rather it is hoped that it will present a more critical analysis of some of the areas where prolactin appears to be involved or at least associated with alterations in the secretion and release of luteinizing hormone $(\mathrm{LH})$ and follicle-stimulating hormone (FSH). To this end, it is first necessary to review briefly the hypothalamic control of prolactin and gonadotrophin secretion followed by an appraisal of the relationship between prolactin and gonadotrophin secretion during the normal oestrous and menstrual cycle. Finally, consideration will be given to the role of hyperprolactinaemia in gonadotrophin secretion, an area which has recently received much attention.

\section{Hypothalamic control of prolactin secretion}

Many experiments confirm that the major hypothalamic influence over prolactin secretion from the anterior pituitary is inhibitory (see MacLeod \& Lehmeyer, 1972; Meites, Simpkins, Bruni \& Advis, 1977; Meites, 1977; Lancranjan \& Friesen, 1978). While it was initially expected that the prolactin inhibitory factor (PIF) would be a small peptide, a growing body of evidence supports the concept that the PIF is dopamine. Using histochemical and immunochemical methods, Fuxe, Goldstein, Hökfelt, Jonsson \& Lidbrink (1974) and Hökfelt et al. (1975) identified a dopaminergic pathway within the tubero-infundibular neurones which appears to control prolactin secretion. This pathway originates mainly from the arcuate nucleus and the ventral part of the anterior periventricular nucleus and ends in the external layer of the median eminence. Here the dopamine nerve terminals are adjacent to the hypophysial portal capillaries which carry the hypothalamic regulatory factors to the anterior pituitary. Cuts made in the hypothalamus which maintained the tubero-infundibular neurone-median eminence intact but isolated it from the rest of the brain had no effect on serum levels of prolactin, whereas increased secretion of prolactin occurred if this connection was severed (Butler, Krey, Lu, Peckham \& Knobil, 1975). Dopamine in vitro and in vivo inhibits prolactin secretion from the pituitary (see MacLeod \& Lehmeyer, 1974, for references). More recently, dopamine has been detected in hypophysial portal vessels at levels which will inhibit prolactin secretion by a direct action on the pituitary lactotrophs (Ben-Jonathan, Oliver, Weiner, Mical \& Porter, 1977; Gibbs \& Neill, 1978; Plotsky, Gibbs \& Neill, 1978; Gudelsky \& Porter, 1979; Ben-Jonathan, 1980). Finally, specific dopamine receptors have been demonstrated on the cells of the anterior pituitary (Brown, Seeman \& Lee, 1976; Caron, Drouin, Raymond, Kelly \& Labrie, 1976), further reinforcing the argument that dopamine is a major, if not the only, PIF.

There is no doubt, however, that agents other than dopamine are involved in the secretion of prolactin. No particular agent has yet been identified as a specific prolactin-releasing factor (PRF). While thyrotrophin-releasing hormone (TRH) releases prolactin as well as thyroid- 
stimulating hormone (TSH), the physiological role of TRH in the control of prolactin secretion remains uncertain. In many physiological situations, such as suckling, sleep and the response to cold stress, prolactin and TSH responses occur independently. Support for the role of TRH came from the demonstration that passive transfer of antiserum to TRH into rats caused a 50 and $70 \%$ decrease in serum levels of prolactin and TSH respectively (Koch et al., 1977). However, such dramatic effects on prolactin secretion were not seen in ewes actively immunized against TRH, even though thyroid function had been reduced by over $50 \%$ (H. M. Fraser, P. Osman \& A. S. McNeilly, unpublished observations).

It is possible that the serotoninergic pathway within the brain is involved in the stimulation of prolactin release. Serotonin (5-hydroxytryptamine) and the serotonin precursor 5-hydroxytryptophan can increase the secretion of prolactin via an action on the hypothalamus (Kamberi, Mical \& Porter, 1971a; Clemens, Sawyer \& Cerimele, 1977) and the suckling-induced release of prolactin is related to an increase in 5-hydroxytryptamine turnover (Mena, Enjalbert, Carbonnell, Priam \& Kordon, 1976).

A most recent development is the demonstration that opiate receptor agonists are powerful releasers of prolactin. Thus both methionine- and leucine- enkephalin and $\beta$-endorphin cause an increase in circulating levels of prolactin (Dupont, Cusan, Caron, Labrie \& Li, 1977; Cusan et al., 1977; Rivier, Vale, Ling, Brown \& Guillemin, 1977) and $\beta$-endorphin has been implicated in both stress- and suckling-induced release of prolactin (Ferland, Kledzik, Cusan \& Labrie, 1978). It has been suggested that $\beta$-endorphin may stimulate prolactin secretion by reducing the release of dopamine from the tubero-infundibular neurones (Van Loon, Ho, Kim, De Souza \& Shin, 1979).

Oestrogens have been shown to increase the secretion of prolactin by an action at both the pituitary and the hypothalamus (see Lancranjan \& Friesen, 1978, for references) and oestradiol can block the inhibitory action of dopamine on the pituitary lactotrophs (Labrie, Baulieu, Caron \& Raymond, 1978). If a similar action was to occur in the hypothalamus, there would be a reduction in the effectiveness of dopamine to inhibit prolactin secretion, resulting in increased release.

Of physiological importance is the auto-regulatory short-loop feedback control of prolactin secretion. High circulating levels of prolactin have been shown to inhibit prolactin release by the pituitary in situ (Meites \& Clemens, 1972; MacLeod, 1974), and increases in the circulating levels of prolactin increase dopamine turnover in the tubero-infundibular neurones of the hypothalamus (Fuxe et al., 1974; Hökfelt et al., 1975; Gudelsky, Simpkins, Mueller, Meites \& Moore, 1976; Advis, Hall, Hodson, Mueller \& Meites, 1977). Since it may be assumed that dopamine is a PIF (Ben-Jonathan, 1980), then the increase in dopamine turnover probably also reflects an increase in dopamine release and therefore will cause the suppression of prolactin secretion by the pituitary in situ. A protein immunochemically similar to prolactin has been detected in the hypothalamus of the rat (Fuxe, Hökfelt, Eneroth, Gustafsson \& Skett, 1977). It is not yet clear whether this material is prolactin, and it may be synthesized in the hypothalamus or represent a binding of prolactin to receptors there. Oliver, Mical \& Porter (1977) have demonstrated that while levels of prolactin in the peripheral circulation of normal rats were around 25 $\mathrm{ng} / \mathrm{ml}$, values of nearly $5000 \mathrm{ng} / \mathrm{ml}$ were found in the long hypophysial portal vessels. Oliver $e t$ al. (1977) suggested that since there appeared to be countercurrent flow of blood within the long portal vessels, then the high levels of pituitary hormones (including prolactin) reaching the hypothalamus by this route could modulate neurotransmitter synthesis and release. It is apparent that an autoregulatory, short-loop negative feedback operates for prolactin and appears to act by increasing the dopamine turnover of the tubero-infundibular neurones.

Since modulation of dopamine output is intimately involved in the control of prolactin secretion, it is important to understand the role of dopamine in the control of gonadotrophin secretion. Initial experiments by Schneider \& McCann (1969) suggested that dopamine stimulated the release of luteinizing hormone-releasing hormone (LHRH) and hence LH. How- 
ever, subsequent studies strongly suggest that dopamine is inhibitory to LHRH release, while brain-stem noradrenergic neurones appear to facilitate LHRH release (see Fink, 1979, for references).

In the rat, infusions of dopamine (Vijayan \& McCann, 1978) or stimulation of dopamine receptors (Drouva \& Gallo, 1977) inhibit the pulsatile secretion of LH. In men and women, short-term infusions of dopamine suppress serum levels of LH (Leblanc, Lachelin Abu-Fadil \& Yen, 1976; Lachelin, Leblanc \& Yen, 1977; Judd, Rakoff \& Yen, 1978), while administration of a dopamine antagonist, metoclopramide (McNeilly, Thorner, Volans \& Besser, 1974), resulted in an acute increase in serum levels of LH and FSH in hyperprolactinaemic patients (Quigley, Judd, Gilliland \& Yen, 1979). While these data clearly suggest an action of dopamine at the hypothalamus, dopamine or the dopamine agonist CB154 may slightly reduce the LH response to LHRH (Judd et al., 1978; McNeilly \& Land, 1979), suggesting an effect directly on the gonadotrophs, although this effect is small (Kamberi et al., 1971a, b). It is unclear whether increased dopamine turnover alone can maintain the suppression of LH and FSH secretion. When dopamine turnover was increased by increased circulating levels of prolactin secreted from donor pituitary grafts in ovariectomized female rats, the suppression of LH pulsatility was not sustained beyond 10 days (Beck, Engelbart, Gelato \& Wuttke, 1977; Beck \& Wuttke, 1977). The increase in hypothalamic dopamine turnover in these animals appeared to be sustained for at least 14 days in spite of elevated prolactin levels (Löfström Jonsson, Wiesel \& Fuxe, 1976). In the absence of the gonads, therefore, the hypothalamus appears to become less sensitive, in terms of LHRH secretion, to the inhibitory effects of the increase in dopamine turnover, as demonstrated by Beck \& Wuttke (1977). In the presence of the gonads, however, suppression of LH and FSH levels is maintained, clearly suggesting an interaction between increased hypothalamic dopamine turnover and the negative feedback effects of gonadal steroids (McNeilly, Sharpe, Davidson \& Fraser, 1978).

\section{Prolactin and the normal pattern of gonadotrophin release}

The most dramatic change in circulating levels of LH and FSH occurs around the time of the preovulatory surge of $\mathrm{LH}$. Before this surge, there is an increase in the pulse frequency of release of LH (Midgley \& Jaffe, 1971; Yen, Lasley, Wang, Leblanc \& Siler, 1975; Baird, 1978), presumably reflecting an increase in the release of hypothalamic LHRH (see Fink, 1979; Lincoln, 1979). The increase in secretion of LH stimulates increased secretion of oestrogens from the developing ovarian follicle(s) and this increase precipitates the preovulatory surge of LH. A peak of prolactin coincident with this surge of LH occurs in the rat (Neill, Freeman \& Tillson, 1971), mouse (Kwa \& Verhofstad, 1967) and hamster (Bast \& Greenwald, 1974). The increase in prolactin in the rat can be prevented by blockade of the pro-oestrous rise in oestradiol by injection of antiserum either to oestradiol (Neill et al., 1971) or LH (Freeman, Reichert \& Neill, 1972). Since oestradiol increases prolactin secretion in the rat (Amenomori \& Meites, 1970 ), it seems probable that the pro-oestrous rise of prolactin in rats occurs as a result of the increase in pro-oestrous oestradiol secretion.

In sheep, a rise in serum prolactin occurs after luteal regression and continues until the end of the ovulatory LH surge (Reeves, Arimura \& Schally, 1970; Cumming, Brown, Goding, Bryant \& Greenwood, 1972; Kann \& Denamur, 1974; Text-fig. 1). Since administration of oestradiol will result in an increase in circulating levels of prolactin (Fell, Beck, Brown, Cumming \& Goding, 1972), it has been suggested that the pro-oestrous rise in prolactin in the sheep, as in the rat, is related to the increasing levels of oestradiol during the periovulatory period. However, a closer examination of the time course of release of prolactin in relation to the secretion of oestradiol suggests that the increase in prolactin occurs before any dramatic change in circulating levels of oestradiol (A. S. McNeilly \& D. T. Baird, unpublished observations; Text- 
fig. 1). This suggests that a factor other than oestradiol may be responsible for the initial increase in release of prolactin. During this initial periovulatory period, the pulse frequency of LH (and by implication LHRH) increases around the same time as the increase in prolactin. Since dopamine appears to be inhibitory to LHRH release, an increase in LHRH release may require a decrease in hypothalamic dopamine turnover. Thus, both the increase in pulse frequency of LH and the increase in circulating levels of prolactin may reflect a decrease in hypothalamic dopamine and the change in prolactin occurs as a consequence and not as a cause of this decreased turnover. That prolactin per se is not implicated in the change in levels of LH is suggested by the fact that, in the cyclic ewe, LH levels, ovulation and luteal function are not

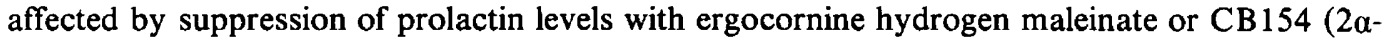
bromo-ergocryptine) (Louw, Lishman, Botha \& Baumgartner, 1974; Niswender, 1974).

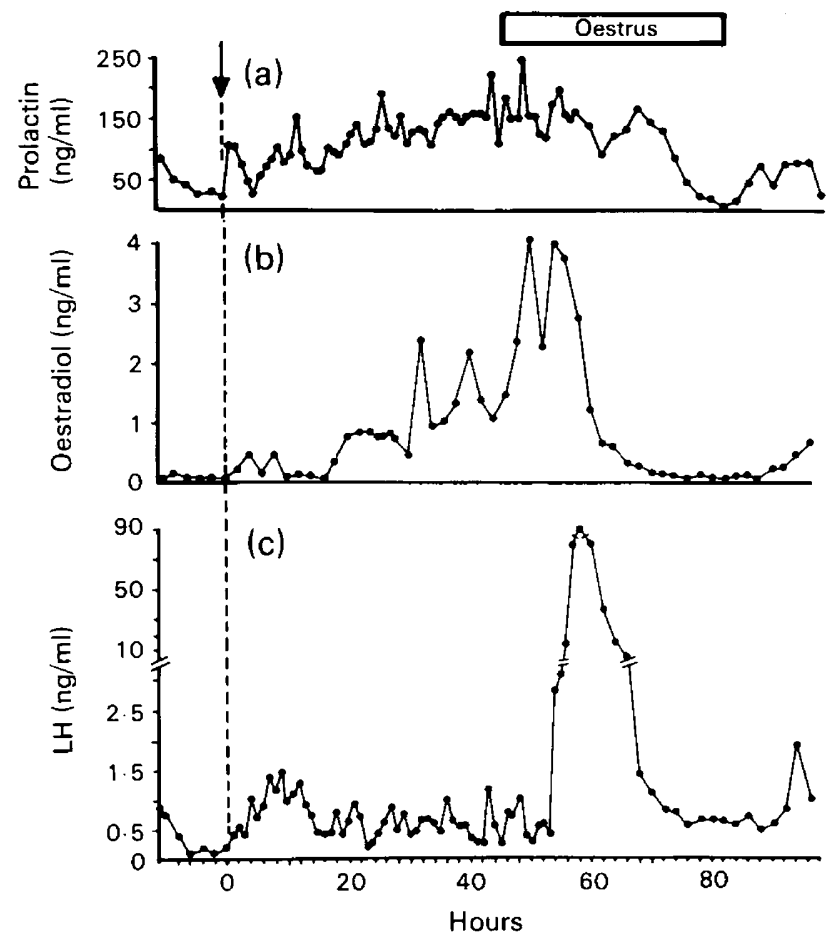

Text-fig. 1. Changes in serum levels of (a) prolactin, (b) oestradiol-17 $\beta$ and (c) LH after induction of luteal regression with a prostaglandin analogue (ICI 80,996: arrow) in a ewe with an ovary transplanted to the neck. Prolactin and $\mathbf{L H}$ were measured in jugular and oestradiol in ovarian venous blood samples. Note the increase in prolactin concentration after the analogue injection followed by a further increase before any significant increase of oestradiol concentrations occurred. (A. S. McNeilly \& D. T. Baird, unpublished observations.)

If increased pulsatile release of LHRH requires a decrease in hypothalamic dopamine turnover, then a concomitant increase in prolactin levels should also be expected. After ovariectomy in the ewe, LH pulse frequency increases to $15-30$ pulses $/ 24 \mathrm{~h}$. This increase is accompanied by an increase in the circulating levels of prolactin (I. J. Clarke \& A. S. McNeilly, unpublished observations; Text-fig. 2). A similar situation arises after ewes are actively immunized against LHRH. Because of the neutralization of LHRH by antibody in the circulation, the secretion of both LH and FSH from the pituitary is dramatically reduced and ovarian follicular development is attenuated. In the absence of gonadal steroids, it may be expected that the hypothalamus responds to an apparent castrated situation with an increase in the secretion of LHRH. 
It is of considerable interest, therefore, that in these ewes circulating levels of prolactin were 410 times higher than in controls (Clarke, Fraser \& McNeilly, 1978). These results suggest the possibility that the rise in plasma prolactin seen at oestrus in the ewe may be related not only to the rise in circulating oestradiol but also to an initial decline in the hypothalamic dopamine turnover. Oestradiol may amplify such an effect by further blocking the action of dopamine at its receptor (Labrie et al., 1978).

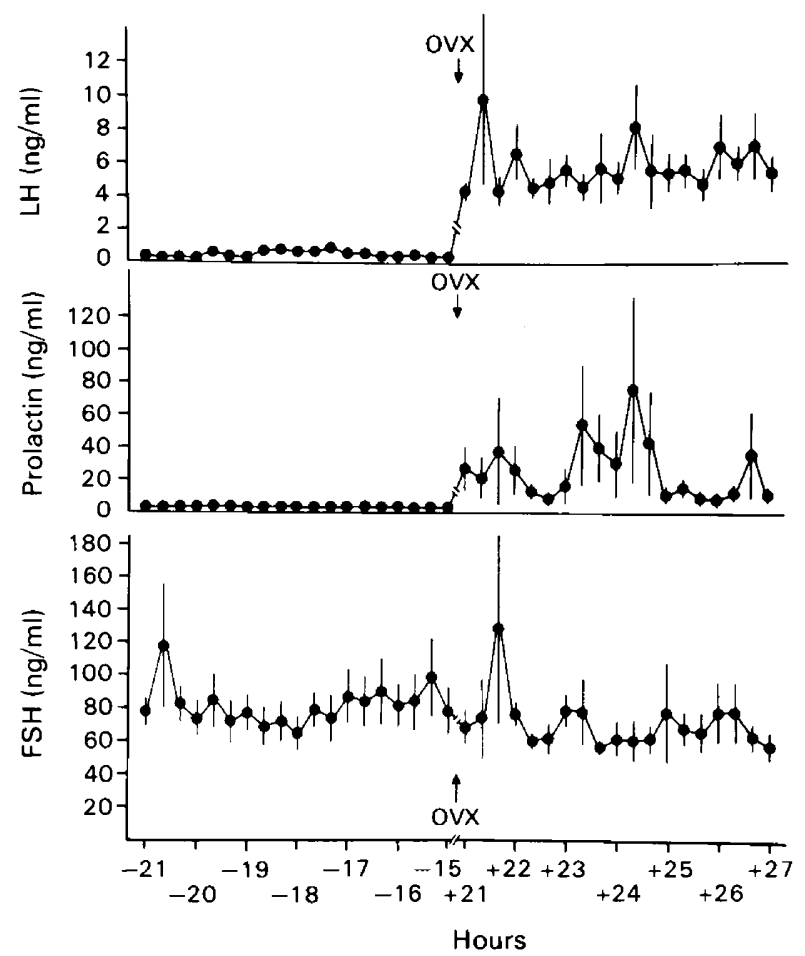

Text-fig. 2. Changes in serum levels (mean \pm s.e.m.) of LH, prolactin and FSH before and after ovariectomy (OVX) in 8 ewes. (I. J. Clarke \& A. S. McNeilly, unpublished results.)

In the chimpanzee (Reyes, Winter, Faiman \& Hobson, 1975), rhesus monkey (Butler et al., 1975), common marmoset (A. S. McNeilly, D. H. Abbott, S. F. Lunn, P. Chambers \& J. P. Hearn, unpublished results) and man (McNeilly \& Chard, 1974), no consistent changes in circulating levels of prolactin have been found throughout the cycle, although prolactin concentrations may be higher at midcycle in women (Robyn et al., 1973). A direct relationship between the levels of oestrogen and prolactin have been reported by some (Robyn et al., 1973; Franchimont et al. (1976) but not by other (McNeilly \& Chard, 1974; Epstein, McNeilly, Murray \& Hockaday, 1975) authors. It is clear that in man, as in sheep, there is an increase in LH pulse frequency before the ovulatory surge of LH (Yen et al., 1975). In the periovulatory period of the menstrual cycle, infusion of dopamine into normal women caused a dramatic decrease in the levels of LH, an effect which was not dependent on the concentration of oestradiol but was related to the increased basal level of LH in the women (Judd et al., 1978). Dopamine infusion earlier in the menstrual cycle was without effect. While basal levels of prolactin were not significantly different between early and mid-cycle, the inhibition of prolactin release by dopamine was correlated with endogenous oestradiol levels. Judd et al. (1978) conclude that "the selective hypersensitivity of both LH and FSH to DA observed on the day 
before the mid cycle $\mathrm{LH}$ peak is consistent with a reduction in LHRH neuronal inhibition by tubero-infundibular DA neurones at this time."

It is clear that in women and sheep the reduced hypothalamic turnover of dopamine in the periovulatory period is similar. It is probable, therefore, that the change in prolactin, if it occurs around the time of the $\mathrm{LH}$ surge, is related not only to the increased secretion of ovarian oestradiol, but also to a decrease in dopamine secretion, and occurs as a consequence and not as a cause of the changes occurring around this time.

\section{Hyperprolactinaemia and lactational amenorrhoea}

Hyperprolactinaemia is associated with lactational anoestrus and amenorrhoea, pathological amenorrhoea and in sheep with seasonal anoestrus. It is not proposed to discuss the latter in this review as this topic has been dealt with by Karsch, Goodman \& Legan (1980). The role of prolactin in lactational amenorrhoea has recently been reviewed (for references, see McNeilly, 1979) and will only be discussed briefly here.

During pregnancy in women, circulating concentrations of prolactin rise to reach values by term that are 4-20 times those in non-pregnant women. This increase in prolactin probably occurs in response to the increasing levels of placental oestrogens during pregnancy. The high steroid concentrations are probably responsible for the reduction in circulating FSH values and pituitary content of $\mathrm{LH}$ at term. After delivery, prolactin concentrations in non-lactating women decline to normal over a 15-20-day period, LH and FSH levels return to normal within about 28 days, with resumption of ovarian follicular development, ovulation and corpus luteum function within 30-40 days (for references, see McNeilly, 1979). In contrast, circulating concentrations of prolactin are maintained by suckling in lactating women, and hyperprolactinaemia may last up to 2 years (Delvoye, Demaegd, Delonge-Desnoek \& Robyn, 1977; Duchen \& McNeilly, 1980). During lactation in women FSH increases to high normal values within 20 days of delivery and remain at this level until ovarian activity resumes. In contrast serum concentrations of $\mathrm{LH}$ increase to low normal values by 20 days but remain low with absent or reduced pulsatility during the period of lactational amenorrhoea. If an adequate suckling frequency and duration is maintained in lactation, pulsatile secretion of $\mathrm{LH}$ remains inadequate to stimulate ovarian follicular development and oestradiol secretion. As the suckling stimulus is reduced in the later stages of lactation, LH secretion increases sufficiently to stimulate follicular development with an increase in circulating oestradiol levels. Nevertheless, during the first 100 days of lactation, women do not show a positive feedback surge of LH in response to this oestradiol (Baird, McNeilly, Sawers \& Sharpe, 1979) and they are more sensitive to the negative feedback effects of oestrogen. Thus, while ovarian follicular development with increased oestrogen can occur during lactation, provided that the suckling stimulus is sufficient and hyperprolactinaemia is maintained, ovulation and normal luteal function will not take place (Duchen \& McNeilly, 1980; A. S. McNeilly, P. W. Howie \& M. Houston, unpublished observations; Text-fig. 3). The pituitary gland during this time contains adequate stores of LH and FSH, as assessed by responses to LHRH (see Jeppson, Rannevik \& Kullander, 1974; Keye \& Jaffe, 1976; Delvoye, Badawi, Demaegd \& Robyn, 1978). It is apparent that high circulating levels of prolactin are related to the maintenance of lactational amenorrhoea (Delvoye et al., 1978; Duchen \& McNeilly, 1980). Maintenance of these levels depends on the maintenance of an adequate suckling stimulus, with long-term hyperprolactinaemia being maintained provided the suckling frequency is more than 6 times per day (Delvoye et al., 1978). Our own data suggest that the prolactin concentration is also related to the total time of the suckling stimulus over a 24-h period (A. S. McNeilly, P. W. Howie \& M. Houston, unpublished observations; Text-fig. 3). Thus, even at a stage of lactation when each suckling episode may not release prolactin, the stimulus is adequate to maintain hyperprolactinaemia (Delvoye et al., 1977, 1978) and inhibit 
the normal release pattern of $\mathrm{LH}$ required for resumption of normal menstrual cyclicity. That the inhibition is readily reversible is demonstrated by the resumption of full ovarian activity with ovulation occurring 14-30 days after weaning, when there is an immediate drop in blood concentrations of prolactin (Rolland, Lequin, Schellekens \& de Jong, 1975). Thus, in women at least, lactation is associated with a period of anovulation, this period being up to or more than 2 years in some instances. Since hyperprolactinaemia in lactation is dependent upon the maintained suckling stimulus, it is unclear whether it is the neural suckling stimulus, the elevated prolactin levels, increased sensitivity to gonadal steroid negative feedback, or a combination of these which is important for the maintenance of lactational anovulation.

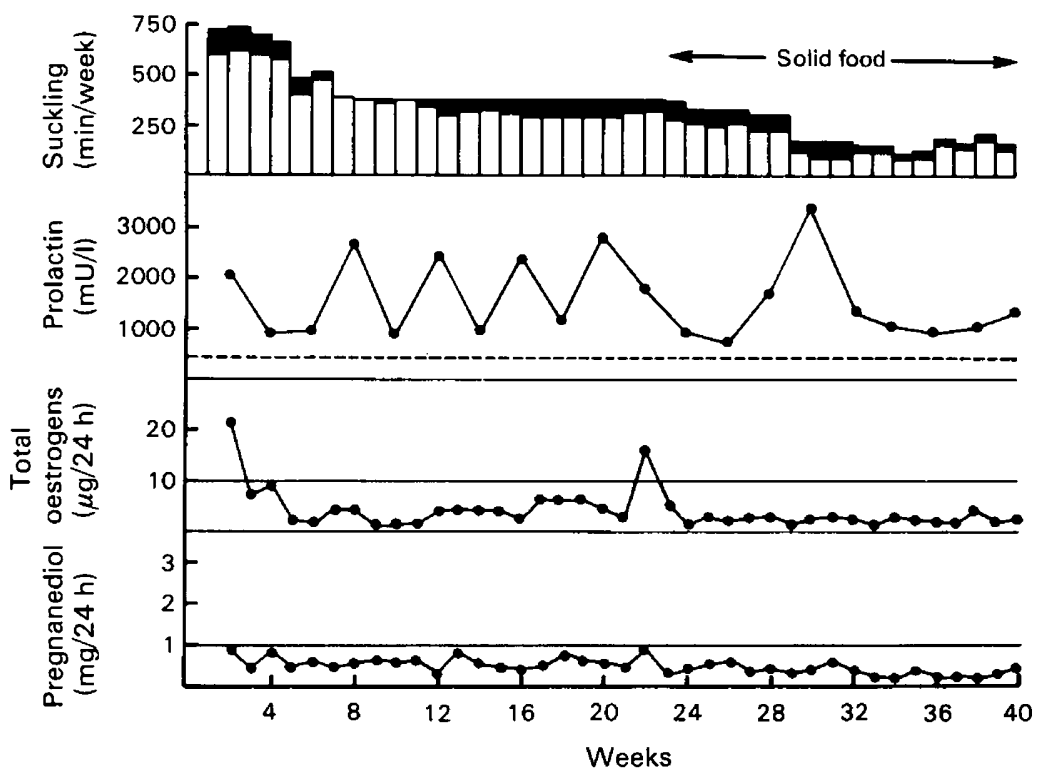

Text-fig. 3. Post-partum changes in urinary total oestrogens and pregnanediol in relation to the total weekly suckling time and serum levels of prolactin in a breast-feeding woman. The total duration of the night-time feed is also indicated (solid columns). (A. S. McNeilly, P. W. Howie \& M. Houston, unpublished results.)

Pathological hyperprolactinaemia in women is associated with amenorrhoea which appears similar to that of lactation. There is no ovarian function, reduced or absent pulsatility of LH secretion, and an absence of positive feedback response to oestrogen (Besser, Parke, Edwards, Forsyth \& McNeilly, 1972; Glass, Shaw, Butt, Logan-Edwards \& London, 1975; Bohnet, Wiest, Dahlen \& Schneider, 1975). When prolactin levels are reduced to normal by the removal of a prolactin-secreting microadenoma or treatment with the dopamine agonist bromocriptine, normal ovarian cyclicity returns. While the use of a dopamine agonist might be interpreted as a repletion of depleted hypothalamic dopamine reserves, removal of a discrete microadenoma secreting only prolactin clearly implicates prolactin per se as a major factor in maintaining the anovulatory state.

Selective pharmacological elevation of prolactin in women with dopamine receptor blocking drugs, e.g. Sulpiride (Robyn et al., 1976) or TRH (Bohnet \& Schneider, 1977), can induce a loss in pulsatile secretion of $\mathrm{LH}$ and of the positive feedback of oestrogen on $\mathrm{LH}$ and FSH and an increase in sensitivity to the negative feedback effects of oestrogen. This further suggests that prolactin may be the causal agent. Nevertheless, in the absence of the gonads, even in the presence of elevated levels of prolactin, gonadotrophin concentrations may be elevated to within the normal post-menopausal range. This suggests that while prolactin may play a vital role, this 
may be to sensitize the hypothalamus to the negative feedback effects of low levels of gonadal steroids.

Evidence from the sheep would support a major role for hyperprolactinaemia in suppressing gonadotrophin secretion during lactational anoestrus. Kann \& Martinet (1975) and Kann, Martinet \& Schirar (1977) showed that the resumption of oestrous activity in sheep was delayed by lactation. Suppression of prolactin secretion either by treatment of ewes with bromocriptine or severance of the neural pathway for the suckling stimulus resulted in an earlier onset of ovarian activity. After neural pathway severence, both the release of prolactin and the neural response to suckling were absolished, while bromocriptine treatment resulted in maintenance of the suckling stimulus but not of the suppression of gonadotrophin secretion. The positive feedback effect of oestrogen on LH and FSH secretion in lactating ewes is suppressed or absent during the first 21 days post partum (Kann et al., 1977; Wright, Findlay, Geytenbeck \& Clarke, 1979), an effect which can be induced in ewes rendered hyperprolactinaemic by repeated injections of TRH (Kann et al., 1977). These results, while not conclusive, suggest that prolactin rather than the suckling stimulus plays the major role in the post-partum inhibition of gonadotrophin secretion in the ewe.

Data for the cow do not support the above observations. It is well recognized that the return to oestrus in suckling cows is delayed compared with that of cows milked only twice daily (see Lamming, 1978). Since there is no difference in serum levels of prolactin in these two situations, the neural suckling stimulus is clearly implicated in the maintenance of lactational anoestrus in the cow (Peters, Vyvoda \& Lamming, 1979).

Over the past few years, many investigators have concentrated efforts on understanding the mechanisms responsible for maintaining lactational anoestrus in the rat. During lactation, ovarian cyclicity is inhibited and serum and pituitary levels of LH and FSH are suppressed (Rothchild, 1960; Ford \& Melampy, 1973; Hammons, Velasco \& Rothchild, 1973; Smith \& Neill, 1977). The LH and FSH response to both LHRH (Lu, Chen, Grandison, Huang \& Meites, 1976a; Smith, 1978a) and oestrogen (Smith, 1978b) are also reduced, suggesting a reduction in hypothalamic stimulation of gonadotrophin secretion. The suckling stimulus alone, in the absence of elevated prolactin levels, led to an earlier resumption of ovarian activity (Lu $e t$ al., 1976b), suggesting that prolactin alone plays an important part in the suppression of gonadotrophin secretion. The relative contributions of the suckling stimulus and the increased prolactin level resulting from this stimulus have been further investigated by measuring the serum LH and FSH responses to ovariectomy during lactation. In the rat the neural stimulus from suckling does not independently suppress LH secretion (Smith, 1978c). During the early stages of lactation the suckling stimulus contributes more than prolactin to the suppression of the post-castration rise in LH but has little effect on FSH. During the second half of lactation the suckling stimulus declines in effectiveness while the relative contribution of prolactin in inhibiting the LH and FSH response to castration increases (Smith \& Neill, 1977; Smith, 1978c).

A complicating feature of lactation in the rat and other rodents is the maintenance of corpora lutea secreting substantial amounts of progesterone. This does not occur in ruminants and primates, and because progesterone has a facilitatory role in the positive feedback effects of oestrogen on LH and FSH secretion during lactation in the rat (Smith, 1978b), interpretations based on data from the rat must be applied with caution to results from other species.

Our own studies have concentrated on investigating the effects of hyperprolactinaemia in the adult male rat. This was chosen because elevation of endogenous prolactin could be achieved by placing pituitary grafts under the kidney capsule, and the male was chosen to overcome the difficulties associated with the ovarian dependence on prolactin in the female rat. Hyperprolactinaemia in the intact adult male rat results in a maintained suppression of serum and pituitary levels of $\mathrm{LH}$ and FSH with no change in the circulating levels of testosterone. The pattern of suppression of LH and FSH was highly suggestive of a reduction in the hypothalamic secretion of LHRH (McNeilly et al., 1978). Removal of the adrenals was without effect on these 
responses (A. S. McNeilly \& R. M. Sharpe, unpublished observations), whereas removal of the gonads resulted in an immediate increase in the serum concentrations of LH and FSH to levels found after castration (McNeilly, Sharpe \& Fraser, 1979). This result clearly suggested that prolactin acted by increasing the sensitivity of the hypothalamus to the negative feedback effects of gonadal steroids, a feature identical to that observed in lactational amenorrhoea in women (Baird et al., 1979) and during seasonal anoestrus in sheep (see Karsch et al., 1980), a time when serum concentrations of prolactin are elevated (Walton, McNeilly, McNeilly \& Cunningham, 1977).

Table 1. Effects of testosterone on the post-castration increase in the mean \pm s.e.m. serum levels of $\mathrm{LH}(\mathrm{ng} / \mathrm{ml}) 10$ days after castration in control and pituitary-grafted (hyperprolactinaemic) adult male rats (no. in parentheses)

\begin{tabular}{lcccc}
\hline & \multicolumn{3}{c}{ Castrated } \\
\cline { 3 - 5 } & & \multicolumn{3}{l}{ Testosterone implant* } \\
\cline { 3 - 5 } & Intact & treatment & $10 \mathrm{~mm}$ & $30 \mathrm{~mm}$ \\
\hline Control & $72 \pm 9$ & $508 \pm 64$ & $12 \pm 2$ & $344 \pm 50$ \\
With pituitary grafts & $(4)$ & $(4)$ & $(8)$ & $(8)$ \\
& $(4)$ & $463 \pm 67$ & $9 \pm 1$ & $20 \pm 6$ \\
& $(4)$ & $(8)$ & $(8)$ \\
\hline
\end{tabular}

* Silastic implants $(10$ or $30 \mathrm{~mm})$ of testosterone were placed s.c. 1 day before castration.

The LH castration response in adult male rats can be prevented by implants containing testosterone but the amount required is three times less than that needed in control castrated rats if the rats also had pituitary grafts maintaining hyperprolactinaemia (A. S. McNeilly \& R. M. Sharpe, unpublished observations; Table 1). This clearly demonstrates that prolactin has increased the sensitivity of the hypothalamo-pituitary axis to the negative feedback effects of gonadal steroids. The mechanism behind this effect remains unknown but may be related to the increase in hypothalamic dopamine turnover induced by the hyperprolactinaemia and indicated by the highly significant decrease in the prolactin content of the pituitary in situ, presumably resulting from increased hypothalamic release of dopamine (PIF).

\section{Conclusions}

During the normal oestrous and menstrual cycles, changes in serum levels of prolactin occur around the time of increased gonadotrophin secretion about ovulation. It is probable that the increase in oestrogen secretion during this periovulatory period plays an important role in increasing prolactin secretion. Nevertheless, since it appears that a decrease in hypothalamic dopamine turnover is necessary to facilitate the required increase in LHRH secretion, the rise in prolactin may merely reflect this decrease in the hypothalamic secretion of dopamine (PIF). The increased secretion of prolactin is probably not directly involved in the normal secretion of LH and FSH at ovulation.

During lactation, high circulating levels of prolactin are associated with an inhibition of gonadotrophin secretion and anoestrus or amenorrhoea result. In women, it is not yet possible to distinguish between the relative roles of the suckling stimulus and hyperprolactinaemia associated with lactational amenorrhoea. Clinical observations in pathological hyperprolactinaemia clearly suggest, however, that elevated serum levels of prolactin alone are sufficient to maintain inhibition of LH and FSH secretion and anovulation. Our recent 
observations with hyperprolactinaemic male rats strongly suggest that elevated levels of prolactin may act by sensitizing the hypothalamus to the negative feedback effects of gonadal steroids.

It is clear, however, that our understanding of the mechanisms behind such an enhancement of sensitivity is very limited and this is an area which requires much more investigation.

\section{References}

Advis, J.P., Hall, T.R., Hodson, C.A., Mueller, G.P. \& Meites, J. (1977) Temporal relationship and role of dopamine in "short-loop" feedback of prolactin. Proc. Soc. exp. Biol. Med. 155, 567-571.

Amenomori, Y. \& Meites, J. (1970) Effect of a hypothalamic extract on serum prolactin levels during the estrous cycle and lactation. Proc. Soc. exp. Biol. Med. 134, 492-495.

Baird, D.T. (1978) Pulsatile secretion of LH and ovarian estradiol during the follicular phase of the sheep estrous cycle. Biol. Reprod. 18, 359-364.

Baird, D.T., McNeilly, A.S., Sawers, R.S. \& Sharpe, R.M. (1979) Failure of oestrogen induced discharge of luteinizing hormone in lactating women. J. clin. Endocr. Metab. 49, 500-506.

Bast, J.D. \& Greenwald, G.S. (1974) Serum profiles of follicle-stimulating hormone, luteinizing hormone and prolactin during the estrous cycle of the hamster. Endocrinology 94, 1295-1299.

Beck, W. \& Wuttke, W. (1977) Desensitization of the dopaminergic inhibition of pituitary luteinizing hormone release by prolactin in ovariectomized ewes. $J$. Endocr. 74, 67-74.

Beck, W., Engelbart, S., Gelato, M. \& Wuttke, W. (1977) Antigonadotrophic effects of prolactin in adult castrated and in immature female rats. Acta endocr., Copenh. 84, 62-71.

Ben-Jonathan, N. (1980) Catecholamines and pituitary prolactin release. J. Reprod. Fert. 58, 501-512.

Ben-Jonathan, N., Oliver, C., Weiner, H.J., Mical, R.S. \& Porter, J.C. (1977) Dopamine in hypophysial portal plasma of the rat during the estrous cycle and throughout pregnancy. Endocrinology 100, 452-458.

Besser, G.M., Parke, L., Edwards, C.R.W., Forsyth, I.A. \& McNeilly, A.S. (1972) Galactorrhoea: successful treatment with reduction of plasma prolactin levels by bromergocryptine. Br. med. J. 3, 669-672.

Bohnet, H.G. \& Schneider, H.P.G. (1977) Prolactin as a cause of anovulation. In Prolactin and Human Reproduction, pp. 71-96. Eds P. G. Crosignani \& C. Robyn. Academic Press, London.

Bohnet, H.G., Wiest, H.J., Dahlen, H.G. \& Schneider, H.P.G. (1975) Die Pulsatile LH-Fluktuation (Spiking) in Abhängigkeit von zirkulierenden Prolaktin Untersuchunger bei physiologischer (Puerperium), bei funktionell pathologischer sowie unter TRH induzieter Hyperprolaktinaemie. Endokrinologie 68, 158-172.

Brown, G.M., Seeman, P. \& Lee, T. (1976) Dopamine/ neuroleptic receptors in basal hypothalamus and pituitary. Endocrinology 99, 1407-1410.

Butler, W.R., Krey, L.C., Lu, H.H., Peckham, w.D. \& Knobil, E. (1975) Surgical disconnection of the medial basal hypothalamus and pituitary function in the rhesus monkey. IV. Prolactin secretion. Endocrinology 96, 1109-1105.

Caron, M.G., Drouin, J., Raymond, V., Kelly, P.A. \& Labrie, F. (1976) Specificity of the catecholaminergic effect on prolactin secretion and $\left({ }^{3} \mathrm{H}\right) \mathrm{di}-$ hydroergocryptine binding. Clin. Res. 24, 656, Abstr.

Clarke, I.J., Fraser, H.M. \& McNeilly, A.S. (1978) Active immunization of ewes against luteinizing hormone releasing hormone, and its effect on ovulation and gonadotrophin, prolactin and ovarian steroid secretion. J. Endocr. 78, 39-47.

Clemens, J.A., Sawyer, B.D. \& Cerimele, B. (1977) Further evidence that serotonin is a neurotransmitter involved in the control of prolactin secretion. Endocrinology 100, 692-698.

Cumming, I.A., Brown, J.M., Goding, J.R., Bryant, G.D. \& Greenwood, F.C. (1972) Secretion of prolactin and luteinizing hormone at oestrus in the ewe. $J$. Endocr. 54, 207-213.

Cusan, L., Dupont, A., Kledzik, G.S., Labrie, F., Coy, D.H. \& Schally, A.V. (1977) Potent prolactin and growth hormone releasing activity of more analogues of Met-enkephalin. Nature, Lond. 268, 544-547.

Delvoye, P.M., Demaegd, M., Delonge-Desnoeck, J. \& Robyn, C. (1977) The influence of the frequency of nursing and of previous lactation experience on serum prolactin in lactating mothers. J. biosoc. Sci. 9, 447-450.

Delvoye, P., Badawi, M., Demaegd, M. \& Robyn, C. (1978) Long lasting lactation is associated with hyperprolactinaemia and amenorrhoea. In Progress in Prolactin Physiology and Pathology, pp. 213232. Eds C. Robyn \& M. Harter. Elsevier-North Holland-Biomedical Press, Amsterdam.

Drouva, S.V. \& Gallo, R. (1977) Further evidence for inhibition of episodic luteinizing hormone release in ovariectomized rats by stimulation of dopamine receptors. Endocrinology 100, 792-800.

Duchen, M.R. \& McNeilly, A.S. (1980) Hyperprolactinaemia and long term lactational amenorrhoea. Clin. Endocr. (In press).

Dupont, A., Cusan, L., Caron, M., Labrie, F. \& Li, C.H. (1977) B-Endotrophin: stimulation of growth hormone release in vivo. Proc. natn. Acad. Sci. U.S.A. 74, 358-359.

Epstein, M.T., McNeilly, A.S., Murray, A.M.F. \& Hockaday, T.D.R. (1975) Plasma testosterone and prolactin in the menstrual cycle. Clin. Endocr. 4, 531-535.

Fell, L.R., Beck, C., Brown, J.M., Cumming, I.A. \& Goding, J.R. (1972) Radioimmunoassay for ovine prolactin. The secretion of prolactin as affected by milking, oestradiol administration and onset of parturition. J. Reprod. Fert. 28, 133-134. 
Ferland, L., Kledzik, G.S., Cusan, L. \& Labrie, F. (1978) Evidence for a role of endorphins in stress- and suckling-induced prolactin release in the rat. Molec. cell. Endocr. 12, 267-272.

Fink, G. (1979) Neuroendocrine control of gonadotrophin secretion. Br. med. Bull. 35, 155-160.

Ford, J.J. \& Melampy, R.M. (1973) Gonadotrophin levels in lactating rats; effect of ovariectomy. Endocrinology 93, 540-547.

Franchimont, P., Dourcy, C., Legros, J.J., Reuterm, A., Vrindts-Gevaert, V., Van Cauwenberge, J.R. \& Gapard, U. (1976) Prolactin levels during menstrual cycle. Clin. Endocr. 5, 643-650.

Freeman, M.E., Reichert, L.E., Jr \& Neill, J.D. (1972) Regulation of the proestrus surge of prolactin secretion by gonadotrophin and estrogen in the rat. Endocrinology 90, 232-238.

Fuxe, K., Goldstein, M., Hökfelt, T., Jonsson, G. \& Lidbrink, P. (1974) Dopaminergic involvement in hypothalamic function: extra-hypothalamic and hypothalamic control. A neuroanatomical analysis. Adv. Neurol. 5, 405-419.

Fuxe, K., Hökfelt, T., Eneroth, P., Gustafsson, J.A. \& Skett, P. (1977) Prolactin-like immunoreactivity: localization in nerve terminals of rat hypothalamus. Science N.Y. 196, 899-900.

Gibbs, D.M. \& Neill, J.D. (1978) Dopamine levels in hypophysial stalk blood in the rat are sufficient to inhibit prolactin secretion in vivo. Endocrinology 102, 1895-1900.

Glass, M.R., Shaw, R.W., Butt, W.R., Logan-Edwards, R. \& London, D.R. (1975) An abnormality of oestrogen feedback in amenorrhoea galactorrhoea. Br. med. J. 3, 274-275.

Gudelsky, G.A. \& Porter, J.C. (1979) Release of newly synthesized dopamine into the hypophysial portal vasculature of the rat. Endocrinology 104, 583-587.

Gudelsky, G.A., Simpkins, J., Mueller, G.P., Meites, J. \& Moore, K.E. (1976) Selective actions of prolactin on catecholamine turnover in the hypothalamus and on serum LH and FSH. Neuroendocrinology 22, 206215.

Hammons, J.A., Velasco, M. \& Rothchild, I. (1973) Effect of the sudden withdrawal or increase in suckling on serum LH levels in ovariectomized postparturient rats. Endocrinology 92, 206-211.

Hökfelt, T., Johansson, O., Fuxe, K., Löfström, A., Goldstein, M., Park, D., Ebstein, R., Fraser, H., Jeffcoate, S., Efendic, S., Luft, R. \& Arimura, A. (1975) Mapping and relationship of hypothalamic hormones. Proc. 6th Int. Congr. Pharmac. 3, 93110.

Jeppson, S., Rannevik, G. \& Kullander, S. (1974) Studies on the decreased gonadotrophin response after administration of LH/FSH-releasing hormone during pregnancy and the puerperium. Am. J. Obstet. Gynec. 120, 1029-1034.

Judd, S.J., Rakoff, J.S. \& Yen, S.S.C. (1978) Inhibition of gonadotrophin and prolactin release by dopamine: effect of endogenous estradiol levels. J. clin. Endocr. Metab. 47, 494-498.

Kamberi, I.A., Mical, R.S. \& Porter, J.C. (1971a) Effects of anterior pituitary perfusion and intraventricular injection of catecholamines on prolactin release. Endocrinology 88, 1012-1020.
Kamberi, I.A., Mical, R.S. \& Porter, J.C. (1971b) Pituitary portal vessel infusion of hypothalamic extract and release of LH, FSH, and prolactin. Endocrinology 88, 1294-1299.

Kann, G. \& Denamur, R. (1974) Possible role of prolactin during the oestrous cycle and gestation in the ewe. J. Reprod. Fert. 39, 473-483.

Kann, G. \& Martinet, J. (1975) Prolactin levels and duration of post partum anoestrus in lactating ewes. Nature, Lond. 257, 63-64.

Kann, G., Martinet, J. \& Schirar, A. (1977) Modifications of gonadotrophin secretion during natural and artificial hyperprolactinaemia in the ewe. In Prolactin and Human Reproduction, pp. 47-59. Eds P. G. Crosignani \& C. Robyn. Academic Press, London.

Karsch, F.J., Goodman, R.L. \& Legan, S.J. (1980) Feedback basis of seasonal breeding: test of an hypothesis. J. Reprod. Fert. 58, 521-535.

Keye, W.R. \& Jaffe, R.B. (1976) Changing patterns of FSH and LH response to gonadotrophin-releasing hormone in the puerperium. J. clin. Endocr. Metab. 42, 1133-1138.

Koch, Y., Goldhaber, G., Fireman, I., Zor, E., Shani, J. \& Tal, E. (1977) Suppression of prolactin and thyrotropin releasing hormone. Endocrinology 100, 14761478.

Kwa, H.G. \& Verhofstad, F. (1967) Prolactin levels in the plasma of female $(\mathrm{C} 57 \mathrm{BL} \times \mathrm{CBA}) \mathrm{F}_{1}$ mice. $J$. Endocr. 38, 81-82.

Labrie, F., Baulieu, M., Caron, M.G. \& Raymond, V. (1978) The adenohypophyseal dopamine receptor. Specificity and modulation of its activity by estradiol. In Progress in Prolactin Physiology and Pathology, pp. 121-136. Eds C. Robyn \& M. Harter. ElsevierNorth Holland-Biomedical Press, Amsterdam.

Lachelin, G.C.L., Leblanc, H. \& Yen, S.S.C. (1977) The inhibitory effect of dopamine agonists on $\mathbf{L H}$ release in women. J. Clin. Endocr. Metab. 44, 728-732.

Lamming, G.E. (1978) Reproduction during lactation. In Control of Ovulation, pp. 335-353. Eds D. B. Crighton, G. R. Foxcroft, N. B. Haynes \& G. E. Lamming. Butterworths, London.

Lancranjan, I. \& Friesen, H.G. (1978) The neural regulation of prolactin secretion. In Current Studies of Hypothalamic Function, pp. 131-150. Eds W. L. Veale \& K. Lederis. S. Karger, Basel.

Leblanc, H., Lachelin, G.C.L., Abu-Fadil, S. \& Yen, S.S.C. (1976) Effects of dopamine in fusion on pituitary hormone secretion in humans. $J$. clin. Endocr. Metab. 43, 668-674.

Lincoln, G.A. (1979) Pituitary control of testicular activity. Br, med. Bull. 35, 167-172.

Löfström, A., Jonsson, G., Wiesel, F.A. \& Fuxe, K. (1976) Microfluorimetric quantitation of catecholamine fluorescence in rat median eminence. II. Turnover changes in hormonal states. J. Histochem. Cytochem. 24, 430-444.

Louw, B.P., Lishman A.W., Botha, W.A. \& Baumgartner, J.P. (1974) Failure to demonstate a role for the acute release of prolactin at oestrus in the ewe. $J$. Reprod. Fert. 40, 455-458.

Lu, K.H., Chen, H.T., Grandison, L., Huang, H.H. \& Meites, J. (1976a) Reduced luteinizing hormone release by synthetic luteinizing hormone releasing 
hormone (LHRH) in postpartum lactating rats. Endocrinology 98, 1235-1240.

Lu, K.H., Chen, H.T., Huang, H.H., Grandison, L., Marshall, S. \& Meites, J. (1976b) Relation between prolactin and gonadotrophin secretion in postpartum lactating rat. J. Endocr. 68, 241-250.

MacLeod, R.M. (1974) Regulation of pituitary function by catecholamines. In Mammary Cancer and Neuroendocrine Therapy, pp. 139-159. Ed. B. Stoll. Butterworth, London.

MacLeod, R.M. \& Lehmeyer, J.E. (1972) Restoration of prolactin synthesis and release by administration of monoaminergic blocking agents to pituitary tumorbearing rats. Cancer Res. 34, 345-350.

MacLeod, R.M. \& Lehmeyer, J.E. (1974) Studies on the mechanism of the dopamine-mediated inhibition of prolactin secretion. Endocrinology 94, 1077-1083.

McNeilly, A.S. (1979) Effects of lactation on fertility. Br. med. Bull. 35, 15.1-154.

McNeilly, A.S. \& Chard, T. (1974) Circulating levels of prolactin during the menstrual cycle. Clin. Endocr. 3, 105-112.

McNeilly, A.S. \& Land, R.B. (1979) Effect of suppression of plasma prolactin on ovulation, plasma gonadotrophins and corpus luteum function in LHRH treated anoestrous ewes. J. Reprod. Fert. 57, 601-609.

MeNeilly, A.S., Sharpe, R.M. \& Fraser, H.M. (1980) Effect of castration on hyperprolactinaemic-induced inhibition of gonadotrophin secretion in the adult male rat. J. Endocr. (In press).

MeNeilly, A.S., Sharpe, R.M., Davidson, D.W. \& Fraser, H.M. (1978) Inhibition of gonadotrophin secretion by induced hyperprolactinaemia in the male rat. J. Endocr. 79, 59-68.

McNeilly, A.S., Thorner, M.O., Volans, G. \& Besser, G.M. (1974) Metoclopramide and prolactin. Br. med. J. 4, 729.

Meites, J. (1977) Neuroendocrine control of prolactin in experimental animals. Clin. Endocr. 6, Suppl. 9s$18 \mathrm{~s}$.

Meites, J. \& Clemens, J.A. (1972) Hypothalamic control of prolactin secretion. Vitams Horm. 30, 165-221.

Meites, J., Simpkins, J., Bruni, J. \& Advis, J. (1977) Role of biogenic amines in control of anterior pituitary hormones. IRCS Med. Sci. 5, 1-7.

Mena, F., Enjalbert, A., Carbonnell, L., Priam, M. \& Kordon, C. (1976) Effect of suckling on plasma prolactin and hypothalamic monamine levels in the rat. Endocrinology 99, 445-451.

Midgley, A.R., Jr \& Jaffe, R.B. (1971) Regulation of human gonadotrophins. $\mathrm{X}$. Episodic fluctuation of LH during the menstrual cycle. J. clin. Endocr. Metab. 33, 962-969.

Neill, J.D., Freeman, M.E. \& Tillson, S.A. (1971) Control of the proestrus surge of prolactin and luteinizing hormone secretion by estrogens in the rat. Endocrinology 89, 1448-1453.

Niswender, G.D. (1974) Influence of $2 \mathrm{Br} \alpha$ ergocryptine on serum levels or prolactin and the estrous cycle in sheep. Endocrinology 94, 612-615.

Oliver, C., Mical, R.S. \& Porter, J.C. (1977) Hypothalamic pituitary vasculature: evidence for retrograde blood flow in the pituitary stalk. Endocrinology 101, 598-604.
Peters, A.R., Vyvoda, S. \& Lamming, G.E. (1979) Comparison of plasma prolactin levels in the milked and suckled cow. J. Endocr. 83, 27P-28P.

Plotsky, P.M., Gibbs, D.A. \& Neill, J.D. (1978) Liquid chromatographic-electrochemical measurement of dopamine in hypophysial stalk blood of rats. Endocrinology 102, 1887-1894.

Quigley, M.E., Judd, S.J., Gilliland, G.B. \& Yen, S.S.C. (1979) Effects of a dopamine antagonist on the relase of gonadotrophin and prolactin in normal women and women with hyperprolactinaemic anovulation. $J$. clin. Endocr. Metab. 48, 718-720.

Reeves, J.T., Arimura, S. \& Schally, A.V. (1970) Serum levels of prolactin and luteinizing hormone $(\mathrm{LH})$ in the ewe at various stages of the estrous cycle. Proc. Soc. exp. Biol. Med. 134, 938-942.

Reyes, F.I., Winter, J.S.D., Faiman, C. \& Hobson, W.C. (1975) Serial serum levels of gonadotrophins prolactin and sex steroids in the nonpregnant and pregnant chimpanzee. Endocrinology 96, 1447-1455.

Rivier, C., Vale, W., Ling, N., Brown, M. \& Guillemin, R. (1977) Stimulation in vivo of the secretion of prolactin and growth hormone by $\beta$-endorphin. Endocrinology 100, 230-241.

Robyn, C., Delvoye, P., Nokin, J., Vekemans, M., Badawi, M., Perez-Lopez, F.R. \& L'Hermite, M. (1973) Prolactin and human reproduction. In Human Prolactin, pp. 167-188. Eds J. L. Pasteels \& C. Robyn. Excerpta Medica, Amsterdam.

Robyn, C., Delvoye, P., Van Exter, C., Vekemans, M., Caufriez, A., de Nayer, P., Delogne-Desnoeck, J. \& L'Hermite, M. (1976) Physiological and pharmacological factors influencing prolactin secretion and their relation of human reproduction. In Prolactin and Human Reproduction, pp. 71-96. Eds P. G. Crosignani \& C. Robyn. Academic Press, London.

Rolland, R., Lequin, R.M., Schellekens, L.A. \& de Jong, F.H. (1975) The role of prolactin in restoration of ovarian function during the early post-partum period in the human female. I. A study during physiological lactation. Clin. Endocr. 4, 15-25.

Rothchild, I. (1960) The corpus luteum-pituitary relationship: the association between the cause of luteotropin secretion and the cause of follicular quiescence during lactation; the basis for a tentative theory of the corpus luteum-pituitary relationship in the rat. Endocrinology 67, 9-14.

Schneider, H.P.G. \& McCann, S.M. (1969) Possible role of dopamine as transmitter to promote discharge of LH-releasing factor. Endocrinology 85, 121-130.

Smith, M.S. (1978a) A comparison of pituitary responsiveness to luteinizing hormone-releasing hormone during lactation and the estrous cycle of the rat. Endocrinology 102, 114-120.

Smith, M.S. (1978b) Hypothalamic-pituitary responsiveness during lactation in the rat: estrogen-induced $\mathrm{LH}$ surges. Endocrinology 102, 121-127.

Smith, M.S. (1978c) The relative contribution of suckling and prolactin to the inhibition of gonadotrophin secretion during lactation in the rat. Biol. Reprod. 19, 77-83.

Smith, M.S. \& Neill, J.D. (1977) Inhibition of gonadotrophin secretion during lactation in the rat: relative contribution of suckling and ovarian steroids. Biol. Reprod. 17, 255-261. 
Van Loon, G.R., Ho, D., Kim, C., De Souza, E.B. \& Shin, S.H. (1979) Hypothalamic dopamine neurons mediate $\beta$-endorphin-induced prolactin secretion. Endocrinology 104 (Suppl.), Abstr. 202.

Vijayan, E. \& McCann, S.M. (1978) The effect of systemic administration of dopamine and aporphine on plasma LH and prolactin concentrations in conscious rats. Neuroendocrinology 25, 221-235.

Walton, J.S., McNeilly, J.R., McNeilly, A.S. \& Cunningham, F.J. (1977) Changes in blood levels of prolactin, LH, FSH and progesterone during anoestrus in the ewe. J. Endocr. 75, 127-136.
Wright, P.J., Findlay, J.K., Geytenbeck, P.E. \& Clarke, IJ. (1979) GnRH responsiveness and the occurrence of estradiol $\left(E_{2}\right)$ induced $\mathrm{LH}$ positive feedback in relation to the resumption of estrous cycles in postpartum ewes. Endocrinology 104 (Suppl.), Abstr. 918.

Yen, S.S.C., Lasley, B.L., Wang, C.F., Leblanc, H. \& Siler, T.M. (1975) The operating characteristics of the hypothalamic-pituitary system during the menstrual cycle and observations of biological action of somatostatin. Recent Progr. Horm. Res. 31, 321356. 